\title{
STABILISASI DIMENSI PADA KAYU TANAMAN KARRI (Eucalyptus diversicolor) DAN JARRAH (E. marginata) - Bagian II : Furfurilasi (Dimensional Stabilization on Regrowth Karri (Eucalyptus diversicolor) and Jarrah (E. marginata) Part II : Furfurylation
}

\author{
Oleh/By : \\ Jamal Balfas
}

Summary

\begin{abstract}
Wood blocks of karri and jarrah measuring $10 \mathrm{~mm}$ (radial) $x 25 \mathrm{~mm}$ (longitudinal) $x 100 \mathrm{~mm}$ (tangential) were ovendried for. 48 hours at $105^{\circ} \mathrm{C}$ prior to treatment. Furfurylation was carried out by soaking wood specimens in a $98 . \%$ furfuryl alcóhol solution containing $1 \%(w / w)$ of $\mathrm{ZnCl}_{2}$ as catalist. Three soaking times, i.e., 12, 24 and 48 hours were used. Treatment results are expressed in terms of weight (WG) and volumetric (VG) gains. The ability of treatment to dimensionally stabilize wood blocks is expressed as antiswelling efficiency (ASE). Results showed that furfurylation imparted substantial increase in weight, volume and dimensional stability of both regrowth eucalypts. Alike acetylation (reported earlier in Part I), furfurylation on karri specimens revealed higher weight gain, volumetric gain and ASE than jarrah. The rate of furfurylation significantly increased with increasing soaking time to 48 hours. Although furfurylation imparted a high degree of swelling reductions comparable to those obtained by acetylation, the furfurylated specimens and a lower ability to resist swelling during prolonged wetting exposure.
\end{abstract}

\section{PENDAHULUAN}

Kayu muda yang diperoleh dari areal hutan tanaman memiliki karakteristik yang berbeda dengan kayu tua yang berasal dari tegakan tua (hutan. alam). Salah satu perbedaan penting adalah sifat kembang/susut (stabilitas dimensi), di mana kayu muda relatif kurang stabil dibandingkan dengan kayu tua dari jenis yang sama (Clark, 1991). Sebagai contoh, pengembangan volumetris pada kayu tua jenis karri (Eucalyptus diversicolor F. Muell) dan jarrah (E. marginata ex Sm.) adalah kurang dari $15 \%$ (Hillis, 1962), sedangkan pengembangan volumetris pada kayu muda dari hutan tanaman adalah sekitar $23 \%$ pada karri dan $17 \%$ pada jarrah (Balfas, 1993a).

Pada tulisan terdahulu telah dilaporkan bahwa perlakuan asetilasi pada kayu karri dan jarrah dapat mengurangi sekitar $80 \%$ dari pengembangan volumetris total (Balfas, 1993b). Namun demikian, asetilasi hanya efektif dilakukan pada kayu kering oven (kadar air kurang dari $5 \%$ ), suhu tinggi $\left(120^{\circ} \mathrm{C}\right)$ dan memerlukan tempat reaksi tertentu. Oleh sebab itu perlakuan asetilasi pada kayu utuh. (solid wood) sampai saat ini masih belum komersial. Cara lain yang relatif mudah dilakukan adalah furfurilasi, yaitu perlakuan stabilisasi dimensi dengan menggunakan resin furfuril alkohol.
Bahan kimia ini dapat diproduksi secara murah melalui pengolahan limbah pertanian, terutama dari limbah tanaman jagung (Goldstein dan Dreher, 1961; Stamm, 1977). Dari berbagai studi yang telah dilakukan sebelumnya diketahui bahwa furfurilasi dapat meningkatkan berbagai sifat keteguhan kayu, serta meningkatkan ketahanan kayu terhadap serangan jamur dan serangga (Goldstein dan Dreher, 1961). Furfurilasi dapat dilakukan dengan cara difusi pada kayu kering udara (kadar air 10 sampai dengan $18 \%$ ), sehingga miembuatnya lebih praktis dari pada asetilasi. Dalam studi ini dilakukan pengujian apakah furfurilasi memiliki efektífitas stabilisasi dimensi yang setaraf dengan asetilasi.

\section{BAHAN DAN METODE}

Penelitian ini dilakukan di Australian Natiomal University, Canberra, Pada akhir tahun 1992, sebagai kegiatan tambahan di luar projek penelitian utama dalam rangka mengikuti program Master of Science. Seluruh bahan yang digunakan dalam penelitian ini diperoleh dari kelebihan bahan yang tersedia untuk kegiatan penelitian utama. Empat puluh potong kayu karri dan jarrah masing-masing berukuran $10 \mathrm{~mm}$ (radial) $\times 25 \mathrm{~mm}$ (longitudinal) $\times 100 \mathrm{~mm}$ '(tangensial) 
dibagi ke dalam empat kelompok; satu kelompok sebagai kontrol dan tiga kelompok lainnya difurfurilasi dengan waktu rendaman berbeda, yaitu 12, 24 dan 48 jam. Semua contoh dikeringkan dalam oven pada suhu $105^{\circ} \mathrm{C}$ selama $48 \mathrm{jam}$, kemudian didinginkan dalam desikator selama 10 menit sebelum penentuan berat dan dimensinya. Furfurilasi dilakukan dengan merendam contoh dalam larutan campuran $98 \%$ furturil alkohol yang mengandung $1 \% \mathrm{ZnCl}_{2}$ sebagai katalis. Setelah perendaman, masing-masing contoh dibungkus dengan kertas alumunium (alumunium foil) kemudian dibiarkan selama 24 jam untuk meratakan penyebaran resin di dalam kayu. Setelah itu kayu dipanaskan pada suhu $120^{\circ} \mathrm{C}$ selama 6 jam dan didinginkan dalam desikator sebelum dilakukan pengukuran berat dan volume contoh. Efektifitas perlakuan furfurilasi ditentukan berdasarkan penambahan berat dan volume kayu, serta efisiensi anti-pengembangan sebagaimana diuraikan pada tulisan terdahulu (Balfas, 1993b). Pengujian pada pengaruh faktor jenis kayu dan waktu rendaman terhadap efektitas furfurilasi dilakukan dengan menggunakan analisis dua faktor (two factors analysis) pada paket Super-anova 1992, Macintosh computer. Perbedaan pengaruh antar taraf pada masing-masing faktor diuji menurut prosedur t-student.

\section{HASIL DAN PEMBAHASAN}

Hasil perlakuan furfurilasi pada kayu karri dan jarrah disajikan pada Tabel 1. Serupa dengan perlakuan asetilasi, kayu yang difurfurilasi mengalami penambahan berat dan volume. Namun demikian, nilai penambahan berat sebesar 5 - $14 \%$ dan penambahan volume sebesar 2 - $6 \%$ pada kayu yang difurfurilasi adalah lebih rendah dibandingkan dengan pertambahan berat (16 $25 \%)$ dan volume (15 - $20 \%)$ pada kayu yang diasetilasi. Perbedaan ini terutama berhubungan dengan perbedaan sifat fisis kedua larutan kimia terhadap kayu. Dalam proses asetilasi, asetat anhidrida mampu memperbesar volume kayu sekitar $23 \%$ di atas nilai pengembangan volume kayu oleh air (Rowell, 1984), sedangkan furfuril alkohol hanya memiliki sedikit pengaruh pengembangan pada kayu (Stamm, 1977). Oleh sebab itu asetat anhidrida memiliki kemampuan yang lebih tinggi untuk mencapai dan bereaksi dengan gugus hidroksil pada dinding sel. Di samping itu furfuril alkohol memiliki ukuran molekul dan viskositas yang lebih besar daripada asetat anhidrida, sehingga kemampuan difusinya ke dalam dinding sel adalah lebih rendah daripada asetat anhidrida.
Tabel 1. Penambahan berat dan volume pada kayu karri dan jarrah karena pengarubi furfurilasi

Table 1. Weight and volumetric gains due to furfurylation

\begin{tabular}{|c|c|c|c|}
\hline $\begin{array}{l}\text { Jenis kayu } \\
\text { (Wood (ype) }\end{array}$ & $\begin{array}{l}\text { Waktu rendaman } \\
\text { (Soaking time) } \\
\text { jamihours }\end{array}$ & $\begin{array}{c}\text { Penambahan berat } \\
\text { (Weight gain) } \\
\%\end{array}$ & $\begin{array}{c}\text { Penambahan volume } \\
\text { Nolumetric gain) } \\
\text { \% }\end{array}$ \\
\hline Karri & $\begin{array}{l}12 \\
24 \\
48\end{array}$ & $\begin{array}{r}7.12 \\
9.64 \\
13.52\end{array}$ & $\begin{array}{l}3.66 \\
4.47 \\
5.60\end{array}$ \\
\hline Jarrah & $\begin{array}{l}12 \\
24 \\
48\end{array}$ & $\begin{array}{r}5.07 \\
8.96 \\
11.42\end{array}$ & $\begin{array}{r}2.14 \\
3.51 \\
4.19\end{array}$ \\
\hline
\end{tabular}

Pertambahan berat dan volume akibat furfurilasi bervariasi menurut jenis kayu dan waktu rendaman. Kayu karri mengalami pertambahan berat dan volume yang lebih besar daripada kayu jarrah. Alasan mengenai hal ini tidak diketahui, namun permeabilitas yang lebih tinggi dan kadar ekstraktif yang lebih rendah pada karri (Balfas, 1993a) memungkinkan furfuril alkohol untuk menembus lebih dalam pada struktur kayu karri dan melangsungkan lebih banyak reaksi dengan polimer pada kayu ini daripada kayu jarrah. Waktu rendaman yang lebih panjang akan meningkatkan penembusan furfuril alkohol ke dalam kayu, sehingga pertambahan berat dan volume kayu meningkat dengan bertambahnya lama waktu rendaman.

Hasil pengukuran pengembangan volumetris pada kayu karri dan jarrah disajikan pada Tabel 2. Furfuri: lasi dapat mengurangi pengembangan volume sẹbanyak $71,85 \%$ sampai dengan 83,14 . pada karri dan 60,20 \% sampai dengan 79,66 \% pada jarrah. Keragaman ini. menunjukkan perbedaan pengaruh jenis kayu dan waktu rendaman terhadap efektititas furfurilasi dalam stabili-sasi dimensi kayu. Pengurangan pengembangan volume

Tabel 2. Pengembangan volume dan efisiensi anti-pengembangan pada kayu karri dan jarrah setelah perendaman selama 24 jam dalam air

Table 2. Volumetric swelling and anti-swelling efficiency of karri and jarrah after 24 hours immersion.

\begin{tabular}{cccc}
\hline $\begin{array}{c}\text { Jenis kayu } \\
\text { Wood type) }\end{array}$ & $\begin{array}{c}\text { Waktu rendaman } \\
\text { (Soaking time) } \\
\text { jam/hours }\end{array}$ & $\begin{array}{c}\text { Pengembangan volume } \\
\text { Volumetric swelling) } \\
\%\end{array}$ & $\begin{array}{c}\text { Efivienai anti- } \\
\text { pengembangian } \\
\text { (ASE) }\end{array}$ \\
\hline \multirow{2}{*}{ Karri } & 0 (control) & 22.77 & $71.85 \%$ \\
& 12 & 6.41 & $78.13 \%$ \\
& 24 & 4.98 & $83.14 \%$ \\
Jarrah & 48 & 3.84 & $60.20 \%$ \\
& 0 & 17.06 & $72.80 \%$ \\
& 12 & 6.79 & $79.66 \%$ \\
& 24 & 4.64 & \\
\hline
\end{tabular}


karena furfurilasi pada kayu karri secara nyata (p < $0,05)$ lebih besar daripada kayu jarrah, dan perlakuan rendaman yang lebih lama memberikan pengaruh stabilisasi yang lebih tinggi pada kedua jẹnis kayu tersebut:

Dibandingkan dengan hasil asetilasi, furfurilasi memiliki efek stabilisasi yang setara dengan asetilasi. Namun demikian, pengamatan pada sifat pengembangan tangensial yang diukur dengan swellometer dalam waktu pengamatan yang lebih lama (48 jam) diketahui bahwa kayu yang diasetilasi memiliki kurva pengembangan yang sejajar dengan pengembangan pada kontrol, sedangkan kayu yang difurfurilasi memiliki kurva pengembangan tangensial yang relatif linier (Balfas, 1993a). Perbedaan ini menggambarkan bahwa perlakuan asetilasi memberikan pengaruh stabilisasi yang lebih permanen daripada furfurilasi. Dengan perkataan lain, furfurilasi lebih berperan sebagai bahan penolak air (water repellant), dan kemampuannya untuk mengürangi pengembangan pada kayu akan menurun dengan bertambahnya waktu kontak antara kayu dengan air. Perbedaan kemampuan stabilisasi dimensi antara asetilasi dan furfurilasi mungkin berhubungan dengan mekanisme modifikasi kayu yang terjadi pada masingmasing perlakuan. Asetilasi menghasilkan struktur molekul hidrofobis pada dinding sel (Norimoto et. al., 1992), sedangkan furfurilasi membentuk suatu struktur hidrofilis yang secara simultan menutup tempat ikatan air pada satu sisi dan membuka tempat ikatan baru bagi aix pada sisi lainnya.

\section{KESTMPULAN}

Berat dan volume kayu karri dan jarrah mengalami peningkatan setelah diberi perlakuan furfurilasi. Peningkatan ini sangat besar pengaruhnya terhadap stabilitas dimensi kedua jenis kayu tersebut. Efektifitas furfurilasi dipengaruhi òleh jenis kayu dan lamả waktu rendaman. Kayı karri lebih mudah difurfurilasi daripada kayu jarrah. Waktu rendaman yang lebih panjang akan mencapai tingkat furfurilasi yang lebih tinggi. Dibandingkan dengan perlakuan asetilasi, pengaruh furfurilasi terhadap stabilisasi dimensi kayu lebih bersifat temporer.

\section{DAFTAR PUSTAK:}

Balfas, J. 1993a. Improving the weathering resistance of glue laminated regrowth karri and jarrah. Master thesis. Department of Forestry, Australian National University, Canberra.

------ 1993b. Stabilisasi dimensi pada kayu tanaman karri (Eucalyptus diversicolor) dan jarrah $(E$. marginata). Bagian I : Asetilasi. Jurnal Penelitian Hasil Hutan 11 (3) : 89 - 91.

Clark, N.B. 1991. Pulpwood quality and value. In : C.M. Kerruish and W.H.M. Rawlins (Ed.) : The young Eucalypt report. Melbourne. Microdata Pty Ltd.

Goldstein, I.S. dan W.A. Dreher. 1961. Stable furfuryl alcohol impregnating solution. Ind. Eng. Chem. 52 (11) : 57 - 58.

Hillis, W.E 1962. The distribution and formation of polyphenols within the tree. In : W.E. Hillis (Ed.) : wood extractives and their significance to the pulp and paper industries. New York. Academic Press.

Norimoto, M.,J. Girl dan R.M. Rowell. 1992. Rheological properties of chemically modified wood : relationship between dimensional and creep stability. Wood and Fiber Sci. 24 (1) : 25 - 35 .

Stamm, A.J. 1977. Dimensional stabilization of wood with furfuryl alcohol resin. In: I.S. Gôldstein (Ed.). wood technology ; chemical aspects. Washington D.C. American Chem. Soc. 